\title{
EVAPOTRANSPIRATION VARIABILITY OF DIFFERENT PLANT TYPES AT ROMANIAN EXPERIMENTAL EVAPOMETRIC MEASUREMENT STATIONS *
}

\author{
Florentina Iuliana STAN ${ }^{12}$, Gianina NECULAU ${ }^{1}$, Liliana ZAHARIA ${ }^{2}$ \\ \& Gabriela IOANA-TOROIMAC ${ }^{2}$ \\ ${ }^{1}$ National Institute of Hydrology and Water Management \\ 97 Şoseaua Bucureşti-Ploieşti \\ Bucharest - Romania \\ stanflorentinaiuliana@yahoo.com ; gianina.neculau@hidro.ro \\ ${ }^{2}$ University of Bucharest - Faculty of Geography \\ 1 Nicolae Bălcescu Boulevard, 010041 \\ Bucharest - Romania \\ zaharialili@hotmail.com ; gabriela.toroimac@geo.unibuc.ro
}

\begin{abstract}
This paper analyses the variability of evapotranspiration for different types of plant: grass, peas, corn, and apple trees. It uses data measured at three evapometric stations in Romania and simulated by the CropWat model. The results show differences between the evapotranspiration of different plant types, and the importance of the foliar surface and of a plant's development stage. Thus, during the growing season (April/May - September), corn and apple tree lose $400-500 \mathrm{~mm}$ of water by evapotranspiration, peas $360-400 \mathrm{~mm}$ and grass $310-330 \mathrm{~mm}$. The highest water volumes are lost in June - July, months with intense vegetation activity. Evapotranspiration is 100 $\mathrm{mm}$ inferior on bare soil than on soil covered by apple trees. These studies will be useful for agricultural purposes in order to estimate the water needs of crops and develop irrigation plans.
\end{abstract}

Keywords: evapotranspiration, experimental evapometric stations, CropWat model, Romania.

\section{Introduction}

Evapotranspiration is a complex climatic parameter with significant practical research interest for estimating soil moisture stocks and water needs for crop growing, particularly during atmospheric and pedological drought periods, and during the growing season; it is also useful for estimating the amounts of water required for irrigation. Given its importance for the water balance, evapotranspiration is often used in hydrological models, and is also a useful indicator in climate change studies (Sandu et al., 2010).

Due to the difficulty of measuring it directly, evapotranspiration is often estimated by indirect methods taking a variety of climatic and energy parameters into account, e.g., the Thornthwaite, Penman, Turc, etc. methods. In Romania, evapotranspiration is a relatively little studied climatic parameter. Information can be found in climate works summarized at national level, among which the most relevant are: Atlasul Climatic al R.S.R. (A Climatic Atlas of the Romanian Socialist Republic, IM, 1966); Atlas. Republica Socialistă România, Section IV - Climate (Academia Română, 1972 - 1979); Clima Republicii Populare Române (Climate of the Romanian People's Republic) (IM, 1962 - 1966) and, more recently Clima României (The Climate of Romania) (ANM, 2008). In Romania, evapotranspiration is usually

\footnotetext{
* This paper was also published in French in the Conference Proceedings of AIC 2014 (Dijon).
} 
estimated indirectly using the Thornthwaite or Penman equations. It is currently measured at 55 stations around the country (11 evapometric stations on lakes, 41 on land, and 3 experimental ones). Evapotranspiration is measured directly with lysimeters only in the experimental stations.

The main aim of this paper is to show the variability of evapotranspiration from bare soil and from soil covered with different types of plant (grass, peas, corn and apple trees), based on direct measurements by experimental stations and using the CropWat model. A secondary aim is to estimate the water needed to irrigate these crops, using the same model.

\section{Data and methods}

The present study exploited several series of climatic data from three experimental evapometric stations belonging to the national evapometric network run by the National Institute of Hydrology and Water Management: Poiana Braşov (in the mountains at an altitude of $936 \mathrm{~m}$ ), Voineşti (in hilly area, $409 \mathrm{~m}$ in altitude) and Căldăruşani (in the plains, 68 $\mathrm{m}$ in altitude) (figure 1). Six parameters were taken into account on a daily scale: evapotranspiration from bare and plant-covered ground (grassland, pea crops, cornfields and apple trees); precipitation; air temperature; relative air humidity; hours of sunshine; and wind speed. The analysis concerned 2012, hydrometeorologically speaking a dry year, especially during the most intense period of plant development. Evapotranspiration was measured directly by Type G1 lysimeters (1 square meter in area); the latter were weighed daily at 7 p.m. in order to determine the difference between the amount of precipitation and the amount of water absorbed by the soil.

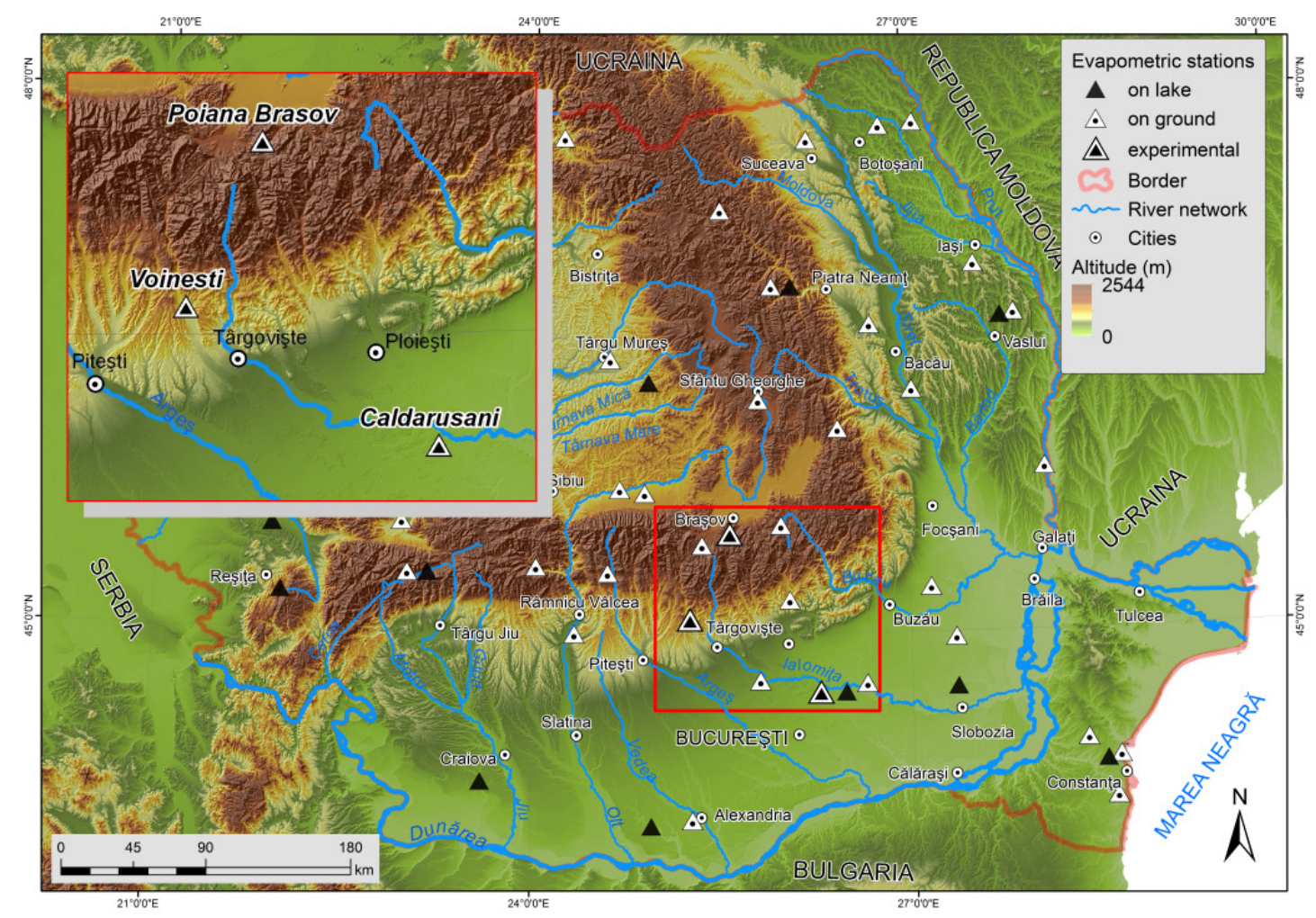

Figure 1: Location of evapometric stations in Romania, and the experimental ones (inset); source: National Institute of Hydrology and Water Management.

In addition to direct data, our analysis also relied on outputs of the CropWat model for potential evapotranspiration, and the water needs of different crop types and for irrigation. 
The CropWat model was created by the FAO Land and Water Development Division (Italy), with support from the Institute of Irrigation and Development Studies in Southampton (United Kingdom) and the National Water Research Center (Egypt). It has been described by Doorenbos and Pruitt (1977), Smith et al. (1992), and Allen et al. (1998), and was applied in Romania by Stăncălie et al. (2010).

The model's input and output data can be classified in four categories: (1) climatic data (monthly rainfall, mean monthly maximum and minimum air temperatures, relative humidity, hours of sunshine, wind speed at $2 \mathrm{~m}$, potential evapotranspiration estimated according to the Penman-Monteith equation); (2) agricultural crop data (crop type, sowing period, standard crop coefficient, plant development stages, root depth, plant withering point, plant response capability, crop yields, plant height); (3) soil data (soil type, maximum rain infiltration rate, maximum root depth, initial soil humidity conditions); and (4) irrigation data (e.g., the criteria for implementing irrigation programs).

The CropWat model can calculate evapotranspiration for crops in two ways: by using the evapotranspiration of reference calculated by the Penman-Monteith equation, or by using the evapotranspiration obtained by direct measurement. In the present study, the evapotranspiration of reference (ETo), was calculated by the Penman-Monteith method, where input consists of maximum and minimum air temperatures, air humidity, sunshine duration and wind speed. Evapotranspiration of crops (ETc) during the growing season is determined as the product of evapotranspiration of reference (ETo) and crop coefficient (Kc) (Equation 1; Allen et al., 1998):

$$
\mathrm{ETc}=\mathrm{ETo} * \mathrm{Kc}
$$

Crop coefficient values for each time lapse are estimated by linear interpolation of $\mathrm{Kc}$ values for each stage of crop development.

\section{Results}

\subsection{Evapotranspiration rates obtained by direct measurement in 2012}

At the Poiana Braşov evapometric station, the lysimeter was covered with grasses specific to the biopedoclimatic mountain stage, forming a pasture. The evapotranspiration measured from May through September totaled $312.8 \mathrm{~mm}$ (table 1).

Table 1: Evapotranspiration (in $\mathrm{mm}$ ) recorded by direct measurement at experimental evapometric stations.

\begin{tabular}{ccccccccc}
\hline Station & Type of plant & April & May & June & July & August & Sept. & Total \\
\hline Poiana Braşov & Grass & - & 59.5 & 60.6 & 96.2 & 73.1 & 23.4 & 312.8 \\
\hline \multirow{2}{*}{ Voineşti } & Bare soil & 36.2 & 77.2 & 78.3 & 67.5 & 61.2 & 31.6 & 352.0 \\
& Apple tree & 45.7 & 93.3 & 99.9 & 85.0 & 83.1 & 39.4 & 446.4 \\
\hline \multirow{2}{*}{ Căldăruşani } & Bare soil & - & - & - & & 48.4 & 27.9 & 76.3 \\
& Peas & 39.4 & 96.3 & 151 & 73.7 & - & - & 360.4 \\
& Corn & 23.8 & 73.1 & 121.9 & 165.2 & 80.6 & 20.9 & 485.6 \\
\hline
\end{tabular}

At the Voineşti evapometric station, there were two lysimeters: one measured evapotranspiration from bare soil, and the other from soil covered with apple tree. Between April and September, evapotranspiration was around $100 \mathrm{~mm}$ higher from the apple-treecovered soil than from the bare soil, the greatest differences being from May through August (table 1 and figure 2). 
At the Căldăruşani experimental station, evapotranspiration was measured from soil covered in peas and corn from April to September (table 1). In August and September, after the peas had been harvested, evapotranspiration was measured from the bare soil. In the case of peas, evapotranspiration totaled $360.4 \mathrm{~mm}$ over the four months of plant growth; the highest monthly value was recorded in June $(151 \mathrm{~mm})$, corresponding to the period of peak growth. With corn, evapotranspiration totaled $485.6 \mathrm{~mm}$ from April to September, when the corn was harvested. The highest evapotranspiration was in June and July, when growth was at its most intense. Comparing the evapotranspiration of the two crops over their mutual growing season shows that evapotranspiration of corn is $25 \mathrm{~mm}$ greater than that of peas (384 $\mathrm{mm}$ v. $360.4 \mathrm{~mm}$ ). The difference is due to corn's intense evapotranspiration in July (the peak growing period), since from April through June peas lose more water from evapotranspiration than corn (figure 3 ).

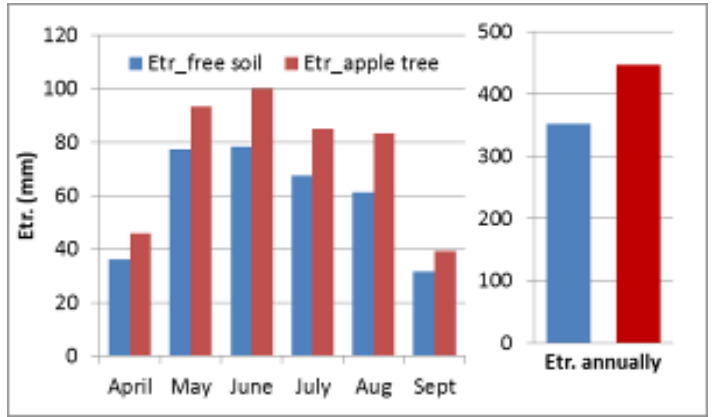

Figure 2: Evapotranspiration from bare (blue) and apple-tree-covered (red) soil at Voineşti.

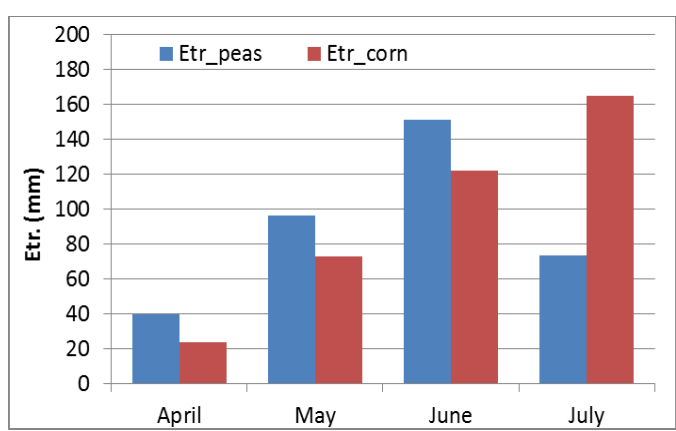

Figure 3: Evapotranspiration from soil covered by peas (blue) and corn (red) at Căldăruşani.

\subsection{CropWat model results}

The CropWat model was applied to obtain the following parameters: evapotranspiration for different crop types, effective rainfall, and water requirements for crop irrigation. The model's input data were the monthly values of the following parameters measured in 2012 at three experimental evapometric stations (Poiana Braşov, Voineşti and Căldăruşani): maximum and minimum air temperatures (in ${ }^{\circ} \mathrm{C}$ ), relative humidity (in \%), hours of sunshine, wind speed at $2 \mathrm{~m}$ (in $\mathrm{m} / \mathrm{s}$ ), and rainfall (in $\mathrm{mm}$ ). Input data for plants were: the types of plant observed in 2012 (grass, corn, peas and apple tree), the standard crop coefficient according to software files, and the characteristics of each stage of crop development. The crop coefficient included the characteristics of each crop and the effects of evaporation from the soil. This depends on climatic and pedological conditions, and its value varies in relationship to the plant's development stages (Bouchet, 1964). The maximum possible value attainable during the peak growing period is 1.20 for corn, 1.15 for peas, 0.95 for apple trees and 0.75 for grass (Allen et al., 1998). Estimated evapotranspiration varies at around $500 \mathrm{~mm}$ for the period from April through September for corn and apple tree (figure 4).

Figure 4: Measured (blue) and CropWat model simulated (red) evapotranspiration.

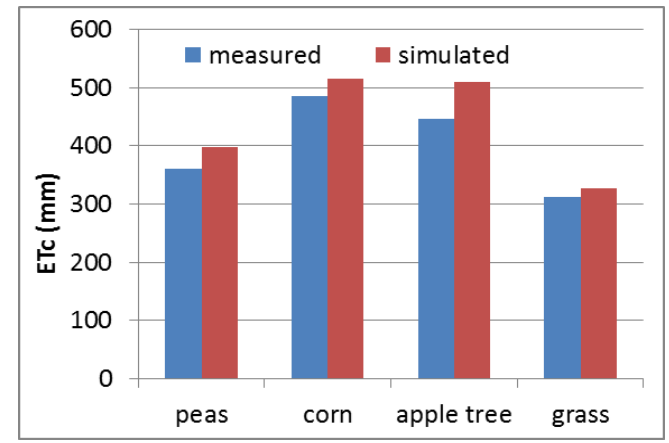


The values simulated by the CropWat model are slightly higher than those obtained by direct measurement - less than $10 \%$ for grass, peas and corn, and $12.5 \%$ for apple tree (figure 4). The highest monthly evapotranspiration values are for corn $(187.6 \mathrm{~mm})$ and peas $(175.3$ $\mathrm{mm}$ ) in June and July (table 2). In addition, maximum evapotranspiration values correspond to the peak growing period of each plant: July for corn, apple trees and grass, and June for peas (figure 5). Water requirements for irrigation vary from $144 \mathrm{~mm}$ for grassland to $341 \mathrm{~mm}$ for corn (table 3).

Table 2: Values simulated by the CropWat model.

\begin{tabular}{|c|c|c|c|c|c|}
\hline \multirow{2}{*}{ Plant } & \multirow{2}{*}{ Month } & \multirow{2}{*}{ Kc } & ETc & Eff. rain & Irr. req. \\
\hline & & & \multicolumn{3}{|c|}{$(\mathrm{mm})$} \\
\hline \multirow[t]{4}{*}{ Peas } & April & 0.5 & 34.4 & 30.9 & 7.5 \\
\hline & May & 0.96 & 108.7 & 120.3 & 16.1 \\
\hline & June & 1.16 & 175.3 & 18.8 & 156.3 \\
\hline & July & 1.11 & 80 & 8.8 & 69.8 \\
\hline \multirow[t]{6}{*}{ Corn } & April & 0.7 & 11.9 & 11.4 & 2.4 \\
\hline & May & 0.7 & 77.7 & 120.3 & 0.0 \\
\hline & June & 0.7 & 109.5 & 18.8 & 90.7 \\
\hline & July & 1.1 & 187.6 & 22.2 & 165.5 \\
\hline & August & 0.8 & 112.0 & 35.5 & 76.4 \\
\hline & Sept. & 0.4 & 16.9 & 12.2 & 5.8 \\
\hline \multirow[t]{6}{*}{ Apple tree } & April & 0.6 & 42.1 & 74.4 & 0 \\
\hline & May & 0.71 & 70.6 & 127.8 & 0 \\
\hline & June & 0.89 & 104.4 & 60.9 & 43.5 \\
\hline & July & 0.91 & 121.9 & 21.6 & 100.3 \\
\hline & August & 0.9 & 102.9 & 18.4 & 84.5 \\
\hline & Sept. & 0.81 & 68.1 & 43.1 & 25 \\
\hline \multirow[t]{5}{*}{ Grass } & May & 0.46 & 35.6 & 130.2 & 0 \\
\hline & June & 0.75 & 79 & 44 & 34.9 \\
\hline & July & 0.75 & 93.7 & 17.2 & 76.4 \\
\hline & August & 0.75 & 73.4 & 45.1 & 28.3 \\
\hline & Sept. & 0.75 & 46.1 & 45.1 & 4.8 \\
\hline
\end{tabular}

Kc - Crop coefficient; ETc- Crop evapotranspiration; Eff. rain - effective rainfall; Irr. req. - water requirements for crop irrigation.

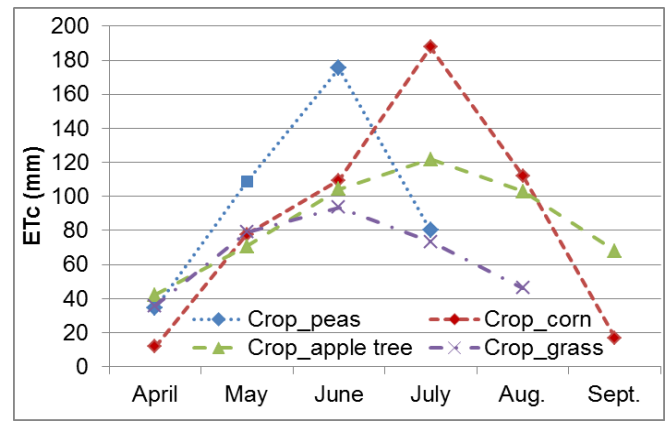

Figure 5: Monthly distribution of evapotranspiration simulated by the CropWat model.

Irrigation is mainly needed when evapotranspiration is high and rainfall is insufficient to ensure normal plant development. The amount of water needed varies from one month to another, with the maximum corresponding to the period of peak growth: $165.5 \mathrm{~mm}$ for corn in July, $156.3 \mathrm{~mm}$ for peas in June, and 100.3 $\mathrm{mm}$ for apple tree in July (table 2 and figure 6).
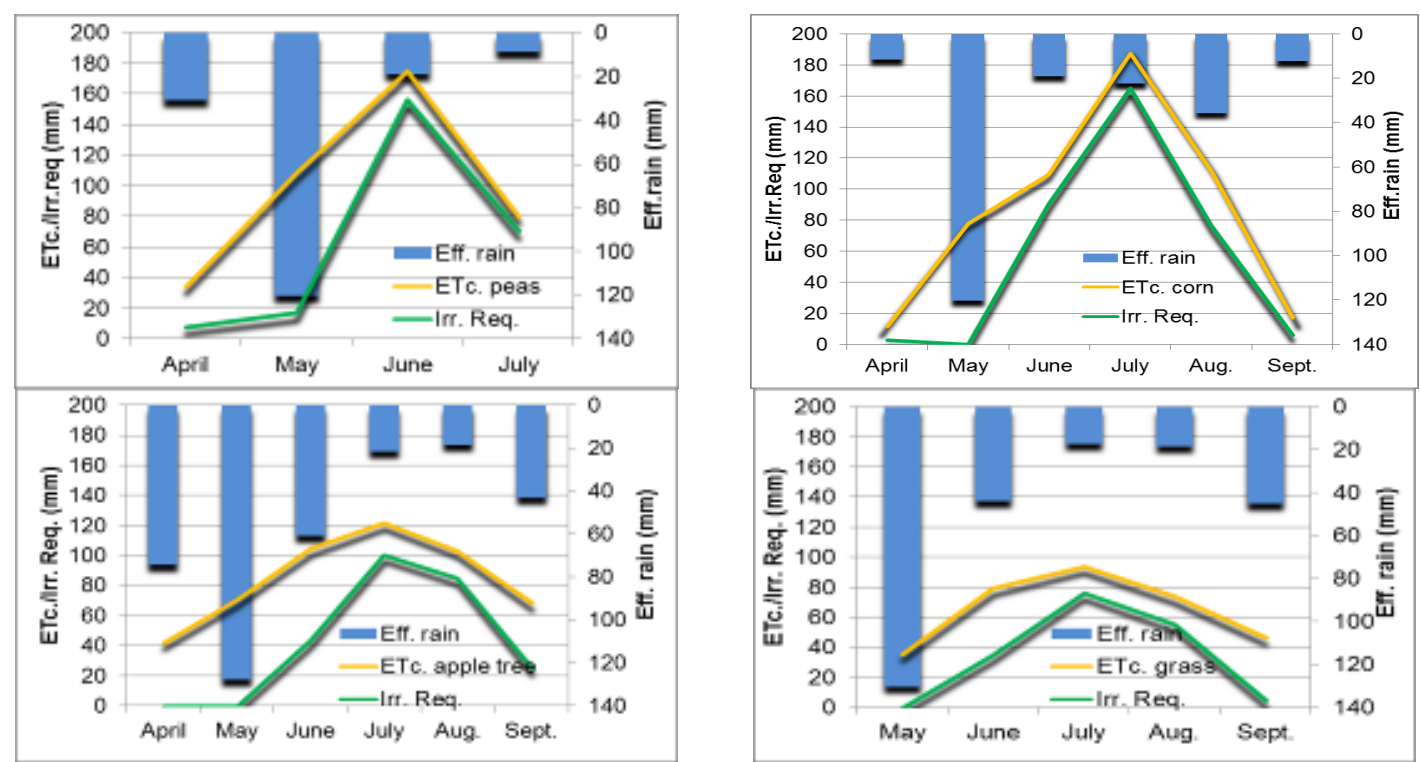

Figure 6: Monthly distribution of values simulated by the CropWat model for different crops (ETc - crop evapotranspiration; Eff. rain - effective rainfall; Irr. req. - water requirements for crop irrigation). 
Table 3: Summarized values of parameters simulated by the CropWat model (for the same periods as table 2).

\begin{tabular}{ccccc}
\hline \multirow{2}{*}{ Stations } & \multirow{2}{*}{ Crop type } & ETc. & Eff. rain & Irr. req. \\
\cline { 3 - 5 } & & & $(\mathrm{mm})$ & \\
\hline \multirow{2}{*}{ Căldăruşani } & peas & 398 & 179 & 250 \\
& corn & 516 & 221 & 341 \\
\hline Voineşti & apple tree & 510 & 346 & 253 \\
\hline Poiana Braşov & grass & 328 & 236 & 144 \\
\hline
\end{tabular}

ETc - crop evapotranspiration; Eff. rain - effective rainfall; Irr. req. - water requirements for crop irrigation

\section{Conclusions}

This paper demonstrates the variability of evapotranspiration from bare soil and from soil covered by different types of plant based on direct measurements made at three experimental stations in Romania and on estimations of the CropWat model. Evapotranspiration from plant-covered soil depends on foliar surface area and the development stage of the plants. Thus, for the growing season (here, 2012) the total evapotranspiration values measured / estimated were $400-500 \mathrm{~mm}$ for corn and apple trees, $360-400 \mathrm{~mm}$ for peas, and $310-330$ $\mathrm{mm}$ for grass. The optimal development of plants requires irrigation, whose requirements in water can be estimated by the CropWat model. This type of study can improve recommendations for irrigation practices, enhance irrigation program planning and enable more accurate estimations of agricultural production under various pluviometric conditions.

\section{References}

Academia Română, 1972-1979: Atlas. Republica Socialistă România (sectiunea IV - Clima). Editura Academiei, Bucureşti, 188 p.

ANM Administrația Națională de Meteorologie, 2008: Clima României, Editura Academiei Române, Bucureşti, 365 p.

ALLEN R., PEREIRA L., RAES, D. SMITH M., 1998: Crop evapotranspiration Guidelines for computing crop water requirements - FAO Irrigation and drainage. Paper 56, FAO, Rome, 301 p.

BOUCHET P. 1964: Évapotranspiration réelle, évapotranspiration potentielle et production agricole, L'eau et la production végétale. INRA, Paris, 151-232.

DOORENBOS J., PRUITT W. O., 1977: FAO Irrigation and Drainage. Paper 24, Rome, 156 p.

Institutul Meteorologic (IM), 1962-1966: Clima Republicii Populare Române. Bucureşti, 166 p.

Institutul Meteorologic (IM), 1966: Atlasul Climatic al R.S.R.. Bucureşti, 189 p.

SANDU I., MATEESCU E., VATAMANU V., 2010: Schimbări climatice în România şi efectele asupra agriculturii. Editura SITECH Craiova, 392 p.

SMITH M., ALLEN R., MONTEITH J.L., PERRIER L., PERRIER A., SEGEREN A., 1992: Report of the expert consultation on the procedures for revision of FAO Guidelines for prediction of crop water requirements. UN- FAO, Rome, Italy, $54 \mathrm{p}$.

STANCĂLIE G., MARICA A., TOULIOS L., 2010: Using earth observation data and CROPWAT model to estimate the actual crop evapotranspiration. Physics and Chemistery of the Earth, 35, 25-30. 